\title{
The Literature Review of Financial Development and Enterprise Financing Constraints on R\&D
}

\author{
Jie $\mathrm{HU}^{1}$, Yu-kun $\mathrm{KOU}^{2, a}$ \\ ${ }^{1,2}$ School of International Business, Shaanxi Normal University \\ Xi'an 710119, China \\ ${ }^{\mathrm{a} C}$ Corresponding author, kouyukun1101@163.com
}

\begin{abstract}
This paper systematically reviews and combs the existing research results of related scholars both at home and aboard, finding out that there are notable financing constraints on enterprise R\&D, and the development of financial market can alleviate the financing constraints of $R \& D$. However, most literatures only consider a single factor for research and analysis, and there are few literatures expound it in angles with multiple factors. This paper will analyze the diversity of enterprise financing constraints on $R \& D$ from multiple perspectives of ownership, scale, region, credit rating, and $R \& D$ tax preference, as well as analyze the mitigation effect of financial development on enterprise $R \& D$ financing constraints under the influence of different firm characteristics.
\end{abstract}

Keywords-Enterprise Financing Constraints on $R \& D ; R \& D$; Financial Development; Credit Rating

\section{INTRODUCTION}

Scientific and technological innovation is a concrete manifestation of a country's social productive forces as well as comprehensive national strength. The development of technology and science is also an important factor for economic growth. As the main part of scientific and technological innovation, enterprise R \& D input is the primary imputes for scientific and technological innovation. More spending on enterprise R\&D is propitious to a long-term, fast and steady economic development [1]. In recent years, the R\&D investment of Chinese enterprises has been steadily increase, and the intensity of R\&D input has been continuously enhanced. However in 2004, Hall and Oriani described in their report about the intensity of $\mathrm{R} \& \mathrm{D}$ input among enterprises in western countries. Thereinto, $4.9 \%$ in the United States, $4.5 \%$ in Germany, $4.2 \%$ in France, $2.9 \%$ in Britain and 3.3\% in Italy, while China invested only $1.6 \%$ in enterprise R\&D in 2015 , which indicated that there was still a huge gap between China and western countries on enterprise R\&D investment; numerous research results also show that significant there are financing constraints on $R \& D$ investment.

Financial development not only provides enterprises with sufficient external funds, but also helps alleviate financing constraints on enterprise investment. Cinka and Brown (2013) thinks the development of financial market can promote the liberalization of the capital market, has a positive effect on the enterprise innovation as well as the intangible assets investment, and protect the interests of investors [2]. Zhai
Shuping and Gu Qun (2013), analyzing with the method of Dynamic panel GMM, found that financial development can significantly alleviate enterprises' financing constraints, and has remarkable effect on promoting $R \& D$ investment efficiency [3]. Wang Wenhua and Zhang Zhuo (2013), based on analyzing the data of A-share high-tech quoted companies, found that raising up financial development level can weaken the dependence of R \& D investment on internal cash flow, and then alleviates the financing constraints of $\mathrm{R} \& \mathrm{D}$ to some extent [4].

So far, many scholars at home and abroad have deeply studied and discussed the financial development relieving enterprise financing constraints on $R \& D$ from a single factor, while few existing literatures discuss the diversity from the perspective of multiple factors of financial development to release enterprise financing constraints on $\mathrm{R} \& \mathrm{D}$. This paper, based on existing literatures, discusses the diversity from the perspective of multiple factors of financial development to release enterprise financing constraints on $\mathrm{R} \& \mathrm{D}$, and tries to understand the financial development relieving enterprise financing constraints on R\&D from multiple aspects, in order to point out new directions to solve the problem of insufficient enterprise investment in R\&D and establish a theoretical basis for promoting the continuous development of $R \& D$ innovation capability of the whole society. Based on the above considerations, the rest of this paper is arranged as follows: the second part discusses the financing constraints on enterprise $\mathrm{R}$ \& $\mathrm{D}$; the third part discusses the mitigation effect on the financial development relieving enterprise financing constraints on $\mathrm{R} \& \mathrm{D}$; the fourth part discusses the characteristics of the different enterprises and the diversity of the financial development relieving enterprise financing constraints on $R \& D$ the fifth part is the summary.

\section{ENTERPRISE FINANCING CONSTRAINTS ON R\&D}

Fazzari (1988) first put forward the concept of financing constraints. Due to the reality of capital market imperfections, when the enterprise is faced with investment opportunities, exorbitant external financing cost and the shortage of internal financing lead the enterprise to facing financing constraints [5]. Due to its large capital requirements, long return cycle and high risk, makes $\mathrm{R} \& \mathrm{D}$ investment face more obvious financing constraints, and is more serious than the average investment [67]. Harhoff (1998) uses data from German manufacturing firms, 
Cincera (2002) uses Belgian corporate data, and Brown (2009) uses data from the American science foundation, these three scholars have reached the unanimous conclusion that there are financing constraints on $\mathrm{R} \& \mathrm{D}$ investment [8-10]. Besides, Mulkay (2001) also compared the diversity in the degree of financing constraint of development between different countries, found that the American Enterprise R \& D financing constraints were stronger than French companies' by analyzing the French and American enterprise data [11].

Feng Wei (1999), who firstly studied the financing constraints, on the basis of the research results of FHP, analyzed the data of 135 listed companies in Shanghai and Shenzhen Chinese manufacturing, and found that China listed companies generally have financing constraints [12]. Furthermore, many scholars have demonstrated the existence of R \& D financing constraints. Xiao Hong (2008) uses the data of Chinese listed companies from 2001 to 2005 to analyze the relationship between $\mathrm{R} \& \mathrm{D}$ expenditure and internal cash flow, and finds that there are financing constraints in $R$ \& D investment of Chinese Enterprises [13]. Tang Qingquan and Xu Xin (2010), Lu Xin (2013), Yao Kaohua (2016) and other scholars based on Chinese financing environment, analyzed whether the R \& D investment facing financing constraints. The research shows that the financing constraints constitute a significant obstacle to the $\mathrm{R} \& \mathrm{D}$ investment of Chinese enterprises, and the mitigation of the financing constraints will contribute to the increase of R \& D investment [14-15]. Zhang Weibin and Liu Ke (2012) taking small and medium-sized listed companies in China's Shanghai and Shenzhen as samples, found that SMEs have significant cash-cash flow sensitivity, which indicates that there are obvious financing constraints for SMEs in China's current financing environment. Gu Qun and Zhai Shuping (2014), based on analyzing the perspective of R\&D heterogeneity, found that there are widespread financing constraints among enterprises; compared to exploitative companies, exploratory companies have higher degree of financing constraints [16].

\section{FINANCIAL DEVELOPMENT RELIEVING ENTERPRISE FINANCING CONSTRAINTS ON R\&D}

The degree of financing constraints on enterprise $R \& D$ largely relies on the external environment of a region, which is the level of financial development. The developed financial market can effectively reduce the problem of asymmetric information, improve the resource allocation efficiency, and thus alleviate the financing constraints of enterprises. Rajan and Zingales (1998) and Claessens and Laeven (2003) analyzed the data of multinational firms, found that the higher level of financial development can effectively reduce incomplete markets as well as the external financing cost, make it easier for enterprises to obtain external funds and market resources, further promote the development of enterprises [1718]. Love (2003) studied the effect of financial development on alleviating the enterprise financing constraints. The study found that financial development can alleviate the financing constraints by reducing information asymmetry and incompleteness of contracts, especially for SMEs [19]. Gorodnichenko and Schnitzer (2010) analyzed developing countries with the data of firm level. Their study found that financial development can promote broadening enterprise financing channels, alleviate financing constraints of external dependence companies, and promote the development of enterprises [20].

With the gradual deepening of China's market-oriented reform, the financing constraints faced by the enterprises in the financial development have also attracted the attention of Chinese scholars. Li Bin and Jiang Wei (2006) found that the financial development level has a significant impact on both short-term and long-term debt financing of listed companies through their research. They also found that raising up financial development can alleviate enterprise financing constraints, and has greater effect on companies relying on external financing to grow. Zeng Wuyi and Zhao Nan(2007) found that regional capital formation is more dependent on the support of financial institutions loans, and financial resources between different provinces in China provide with different influence on the capital formation; at the same time, the region which has higher level of financial development has more active financial market, greater free flow of capital. Enterprises in this region are more convenient to obtain credit and face with less financing constraints. Rao Chunhua (2009) empirically studied the influence of Chinese financial development degree on the development of financing constraints of listed companies. The study found that the presence of financing constraints Chinese listed companies, and financial development especially the development of financial intermediation can effectively alleviate the financing constraints of R \& D investment. Shen Hongbo, Wang Kou (2010), Xie Weimin and Fang Hongxing (2011) using China listed companies as a sample, found that financial development eases the financing constraints of enterprises, and has a positive impact on the company R \& D investment, especially for private enterprises. Yang Fang (2014) found that the higher the level of financial development, the more it can alleviate the investment and financing constraints as well as debt financing constraints of enterprises. Dai Xiaoyong and Cheng $\mathrm{Li}(2005)$ using the method of mathematical model for their analysis, found that financial development can effectively alleviate the financing constraints, the promoting effect of financial development on enterprise $\mathrm{R} \& \mathrm{D}$ investment is more prominent for small and mediumsized enterprises with a strong degree of constraints.

\section{UNDER DIFFERENT CHARACTERISTICS OF ENTERPRISES, THE DIVERSITY OF THE FINANCIAL DEVELOPMENT RELIEVING ENTERPRISE FINANCING CONSTRAINTS ON R\&D}

The effect of nature of property rights on enterprise financing constraints mainly reflected by the soft budget constraint enjoyed by SOE. During the capital rationing, banks and other financial institutions will give priority to provide credit support to large state-owned enterprises have the guarantee condition, compared with state-owned enterprises, continues to support private enterprises is difficult to obtain funds for R \& D investment. Konai (1980) pointed out that the socialist state government's paternal love makes the government a fatherly concern of state-owned enterprises, and gave them more preferential policies and resource support which will reduce the state-owned enterprise financing constraint level and increase the unfairness of state owned 
enterprises and private enterprises. Li Chen and Zhang Ji (2005) found that the sensitivity of investment to cash flow decreases with the increase of the proportion of state-owned shares, and there is no significant correlation between the sensitivity of investment and cash flow. Tang Jianxin and Chen Dong (2009), considering the nature of the actual controller and political relations, their study found that financial development can significantly alleviate the financing gap of small and mediumsized private enterprises without political relations. Wang Jiao (2011), with the analysis of the data of listed companies of Chinese manufacturing in Shanghai and Shenzhen, found that financial development can significantly improve the financing constraints faced by enterprises, and the financial constraints of private enterprises to improve the effect of state-owned enterprises are more obvious.

With the guidance of the national macro policy, the investment and financing activities of enterprises have not reached the level of free competition, where corporate investment and financing activities are more likely to win by virtue of their own size and strength. Therefore, large enterprises as well as large project investment will be given relatively expectations of low risk with high return, and are more likely to be optimistic about the financial institutions. Thus, they face with smaller degree of financing constraints. Beck (2005) analyzed the data of 36 manufacturing sectors in 44 countries from 1980 to 1990, and found that the more developed the financial system is, the better the growth of the industries dominated by small enterprises have. Meanwhile, Beck (2008) analyzed the micro data of three thousand enterprises among 48 countries in world business environment survey, the financing mode of small and medium sized enterprises depends largely on the level of financial development, and the development of financial intermediary and the stock market broaden SMEs external financing channels, to further increase the availability of foreign funds. Zhang Ruiwen and Wu Chengfeng (2014) found that financial development can alleviate the financing constraints of enterprises, and financial development is more significant to alleviate the financing constraints of small and medium-sized enterprises.

From the perspective of the state, enterprises in country with higher financial development obviously face with lower degree of financing constraints than those in lower financial development country. Similarly, studying from different regions in same country, we can find that the uneven development of regional financial development will lead to the impact of financial development on enterprise R\&D investment, which has a regional difference effect. Demirguc-kunt and Maksimovic (1998) found that the regional financial development level of developed can not only provide adequate external funding for enterprises, but also can ensure the investors to obtain corporate investment and financing decision-making information, so that enterprises easier access to external funds and market resources, to further promote the development of enterprises. China is vast in territory and is in process of transformation with many differences from western countries; it is in an immature transition process to mature, from underdeveloped to prosperous. One of the most important manifestation is the unbalanced regional financial development.
However, this unique financial environment provides a good practical research background to investigate the effect of China's financial development investment and financing decisions of enterprises. Therefore, Ning Yanjun (2011) found that the improvement of regional financial development can significantly reduce the cash flow sensitivity of listed companies. Dun Chuang and Xue Li (2006) analyzed the data of China high-tech listed companies in Shanghai and Shenzhen, finding that characteristics of China's R \& D investment are of two significant points. First, the eastern regions are higher than the western region; second, the diversity between region to region is just as it differs from the region itself.

From external factors, credit rating plays an important role in the development of enterprises. It is an effective benchmark to assess the credibility and quality of enterprises, and provides important reference for investors to provide financial support to enterprises. Meanwhile, the difference between the enterprise credit rating will cause different degrees of financing constraints on enterprise R \& D investments. High credit rating companies sent a positive signal with good credit to investors, who are more willing to provide funds, and these companies have a strong ability to repay and lower the risk of default. Compared to low degree of credit rating companies, the high credit rating enterprises are obviously have lower financing constraints degree, and are easier to get a reasonable cost of financing to obtain external funds for R \& D investment, even without the need of relying on financial development to ease the financing constraints faced by enterprises $R$ \& $D$ investment.

At the same time, from the perspective of institution, R\&D preferential tax policy as a long-term and efficient incentives to reduce the cost of enterprise $\mathrm{R} \& \mathrm{D}$ activities, thereby stimulating enterprises to increase investment in R \& D scales. Koga (2003) taking Japanese manufacturing enterprises as samples, found that enterprises that enjoy R\&D preferential tax policies effectively stimulate $\mathrm{R} \& \mathrm{D}$ investment of enterprises, while those which are not able to make use of $R \& D$ preferential tax policies have higher financing costs and strong dependence on external financing. Gui Binwei found that the development of financial market will effectively promote enterprises with higher financing costs.

\section{CONCLUSION}

Based on the above reviews, we can see that the development of the financial market can improve the efficiency of resource allocation, and to some extent, it inhibits the development of informal financing channels and informal financing. At the same time, financial development can decrease the degree of information asymmetry; reduce agency cost, the identification of innovative enterprises and the potential risks of dispersed enterprises; provide convenience and support for enterprise innovation activities; ease the financing constraints; further promote the enterprise investment. From the internal factors, which are ownership and scale of enterprises, the financial development has a significant effect on alleviating financing constraints of private enterprises and SMEs on R\&D investments. In the meantime, regional as well as credit rating and institutional $\mathrm{R} \& \mathrm{D}$ preferential tax policies will make the financing constraints of enterprises significant 
differences. The mitigation role which the financial development plays is significantly different.

\section{REFERENCES}

[1] Du Xing-qiang,Zeng Quan,Du Ying-jie.Do Political Connections Curb R\&D Investment of Chinese Listed Firms ? [J].Review of Investment Studies,2012,06:98-113.

[2] Cinka Borisova,James R Brown. R\&D Sensitivity to Asset Sale Proceeds:New Evidence on Financing Constraints and Intangible[J]. Journal of Banking \& Finance,2013,37(1):159-173

[3] Zhai Shu-ping,Gu Qun.Research on Financial Development,Financial Constraints and R\&D Investment Efficiency of $\mathrm{Hi}-$ tech Enterprises[J]. Economic Survey,2013,02:138-143.

[4] Wang Wen-hua,Zhang Zhuo.Financial Development, Government Subsidies and Financing Constraints of R\&D[J]. Research on Economics and Management,2013,11:51-57.

[5] Fazzari S,Hubbard R G,Petersen B C. Financing Constraints and Corporate Investment[J]. Brookings Papers on Economic Activity, 1988,19(1):141-206.

[6] Hall B H. Investment and Research and Development at the Firm Level : Does the Source of Finance Matter?[R].NBER Working Paper,No.4096,1992.

[7] Himmelberg C P,Petersen B C. R\&D and Internal Finance: a Panel Study of Small Firms in High-tech Industries[J].The Review of Economics and Statistics, 1994,71(1):38-51.

[8] Harhoff D. Are There Financing Constraints for R\&D and Investment in German Manufacturing Firms?[J].Annalesd'Economie et de Statistique49/50,1998:421-456.
[9] CINCERA M. Financing Constraints,Fixed Capital and R\&D Investment Decisions of Belgian Firms[R]. Working Paper Research Series.National Bank of Belgium,2002.

[10] Brown J R, Fazzari S M, Petersen B C. Financing Innovation and Growth : Cash Flow,External Equity and the 1990s R\&D Boom[J].Journal of Finance,2009,64(1) : 151-185.

[11] Mulkay B,Hall B H,Mairresse J. Firm Level Investment and R\&D in France and in the United States[A].Deutsche Bundesbank,(ed.)Investing Today for the Word Tomorrow[R].Springer Verlag,2001,64(1):229-273.

[12] Feng Wei. The Internal Cash FlowAnd Companies' Investments[J]. Economic Science,1999,(01):51-57.

[13] Xiao Hong.R\&D investment Internal financing technical efficiency: Empirical Evidence from 2001-2005 listed companies in Shanghai and Shenzhen[J]. China Financial Research Network,2008.

[14] Tang Qing-quan,Xun Xin.R\&D Investment and Internal Finance:the Research on Chinese Listed Companies [J]. China Accounting Review,2010,03:341-362.

[15] Yao Kao-Hua,Nie Yan,Hong Yun.Credit Rating, Debt Financing Constraints and R\&D Investment[J]. Friends of Accounting,2016,16:7681.

[16] Gu Qun,Zhai Shu-ping.Financial Constraints,R\&D Investment and Funding Sources:The Perspective of R\&D Heterogeneity[J]. Science of Science and Management of S.\&.T,2014,03:15-22.

[17] Rajan R,Zingales L.Financial dependence and growth[J]. American Economic Review,1998,88(3) : 559-586.

[18] Claessens S,Laeven L. Financial Development,Property Rights and Growth[J]. Journal of Finance,2003,58(6) : 2401-2436.

[19] Love I. Financial Development and Financing Constraints[J]. Review of Financial Studies,2003,16(3) : 765-791.

[20] Yuriy Gorodnichenko, Monika Schnitzer,Financial Constrains and Innovation:Why Poor Countries Don’t Catch Up,NBER Working Paper, vol.3, pp.15792, 2010 